\title{
Management of Tuta absoluta Meyrick (Lepidoptera: Gelechiidae) Using Biopesticides on Tomato Crop under Greenhouse Conditions
}

\author{
Abdel Kader El Hajj ${ }^{1}$, Helen Rizk ${ }^{2}$, Mariam Gharib ${ }^{2}$, Maysaa Houssein ${ }^{1}$, Vera Talej ${ }^{1}$, Nour Taha ${ }^{1}$, \\ Soha Aleik ${ }^{1} \&$ Zinette Mousa $^{3}$ \\ ${ }^{1}$ Lebaa Station, Lebanese Agricultural Research Institute, Lebanon \\ ${ }^{2}$ Faculty of Agricultural Science, The Lebanese University, Dekwane, Beirut, Lebanon \\ ${ }^{3}$ Laboratory of Entomology, Lebanese Agricultural Research Institute, Lebanon \\ Correspondence: Abdel Kader El Hajj, Lebaa Station, Lebanese Agricultural Research Institute, P.O. Box 287, \\ Zahle, Tal Amara, Bekaa, Lebanon. Tel: 961-7-230-014. E-mail: ak.hajj@lari.gov.lb
}

Received: June 4, 2017

Accepted: September 15, 2017 Online Published: October 15, 2017

doi:10.5539/jas.v9n11p123

URL: https://doi.org/10.5539/jas.v9n11p123

\begin{abstract}
Tuta absoluta is the major insect invading tomato crop under greenhouse and open field conditions in Lebanon. Farmers mainly depend on chemical control to reduce damage caused by the larva. The hazard use of chemical agents can lead to resistance accumulation. The objective of this study is to investigate alternative agents like biopesticides to control this pest. Two field trials were conducted at the Lebanese Agricultural Research Institute (LARI) for two years under greenhouse conditions. In 2014, the first trial was conducted in two greenhouses: 1-control greenhouse without insect proof net (CG); 2-double door Greenhouse with insect proof net (DDG). In 2015, the second trial was conducted only in control greenhouse.Four treatments and control (not treated plot) were adopted in both trials. The biopesticides used in this study were Neem azal and Bacillus thuringiensis. Results of the first trial showed that using insect proof net reduced the captured adults on the water trap as compared with control greenhouse and thus reducing the damaged caused by the larva of tomato leaf miner on leaves and fruits. The adopted treatments have shown significant differences in the number of mines/leaf, live larva/leaf and percent of damaged fruits in both trials compared to the control. Applying Bacillius thuringiensis and neem azal separately and mixing them together have shown a promising alternative method to chemical control.
\end{abstract}

\section{Introduction}

Tomato leafminer (Tuta absoluta, Meyrick Lepidoptera: Gelechiidae) is currently recognized as a major threat to tomato production in both greenhouse and open field conditions. The moth originates from South America and was spread to Europe, North Africa, Asia and recently in the Middle East over the past ten years (Desneux, 2011; FAO, 2016; Alberto Urbaneja, 2012). Their larvae damage leaves, fruits, and stems (Savino et al., 2012), causing considerable losses on tomato yield. Losses of $50-100 \%$ have been reported on tomato (EPPO, 2005; Gebrelebanos, 2015). Tomato leafminer has a high reproductive potential (Cuthbertson et al., 2013). In favorable conditions, the insect can complete about 10-12 generations in a year (IRAC, 2011; NAPPO, 2012). Tomato leafminer is difficult to control because the larvae feed inside the plant (Guedes et al., 2012; Gebrelebanos, 2015) and their capability to develop resistance to synthetic insecticides (IRAC, 2011; Guedes et al., 2012; Siqueira et al., 2010). Resistance to pyrethroid (Siqueira et al., 2010), abamectin (Siqueira et al., 2001; Guedes et al., 2011; Lietti et al., 2005), cartap (Siqueira et al., 2001; Siqueira et al., 2000), permethrin, methamidophos (Siqueira et al., 2001; Lietti et al., 2005) and spinosad (Campos et al., 2014) used to control tomato leaf miner has been reported.

In Lebanon, control of tomato leaf miner mainly depends on chemical insecticides. Mass trapping is a viable alternative method (Lobos et al., 2013), however, Megido et al. (2013) reported that sex pheromone-based strategy is sometimes more expensive than conventional chemical control. Therefore, the development of control strategies based on the use of bioinsecticides as alternatives to synthetic insecticides should be encouraged due to their potent effects on insect pests, low mammalian toxicity, low persistence in the environment, and biodegradability (EPPO, 2005; Khater, 2012; Koul et al., 2004). Thus, organic molecules of botanical origin may offer a safe source of compounds for pest management, being environmentally friendly, and an excellent 
alternative to persistent synthetic insecticides (Biondi et al., 2006). Neem seed extract active ingredient azadiractin $1 \%$, acts as antifeeding, deterrent and growth inhibitor against a number of insects and mites including tomato leaf miner (Marčić et al., 2009; Koul et al., 2004).

Bacillus thuringiensis $(\mathrm{Bt})$ is used as a biopesticide agent against tomato leaf miner by producing a toxic crystal protein that affects larval stage of many Lepidoptera species. Bt was mentioned in (Gonzalez-Cabrera, J et al.,2011) work to be effective against tomato leaf miner .Mixing Neem Azal \% with Bt was reported to have a high selective toxicity on T. absoluta and low negative effect on their predators (Nazarpour1 et al., 2016).

Some biopesticides were reported not to cause harm to natural enemies (Shabozoi et al., 2011), but the sublethal effect of azadirachtin on predator should not be ignored (Judit et al., 2011). Applying Bt as a biopesticide proved to be safe for generalist parasitoid of Tuta absoluta (Biondi, 2013).

The objective of this study is to investigate the effect of neem azal and $\mathrm{Bt}$ on $T$. absoluta under greenhouse condition in Lebanon.

\section{Materials and Methods}

Two trials were conducted at the Lebanese Agricultural Research Institute (LARI) in Lebaa station $\left(33^{\circ} 32.681^{\prime}\right.$ North, $35^{\circ} 27.088^{\prime}$ East, $354 \mathrm{~m}$ a.s.l.), south Lebanon, province of Jizzin, under greenhouse conditions during the 2014-2015 spring seasons. The Newton variety was used in both trials. In 2014, the first trial was performed in two greenhouses in order to compare the effect of maintenance type of the greenhouse on the insect density. The first one is a double door greenhouse closed tightly with an insect proof net (DDG). The second greenhouse was kept without insect proof net (Control greenhouse-CG). Both greenhouses were with the same area $\left(256 \mathrm{~m}^{2}\right)$. In 2015, the second trial was performed only in control greenhouse (CG). In both trials, the selected bioinsecticides (Neem Azal (1\%) and Bacillus thuringiensis var. Kurstaki, $32 \mathrm{MIU} \mathrm{g}^{-1}$ [millions of International Units per gram]) were assigned to 4 treatments as follow:

Treatment I (NA10): Neem Azal sprayed at 10 days frequency ( $60 \mathrm{ml} / 20 \mathrm{~L}$ water);

Treatment II (NA15): Neem Azal sprayed at 15 days frequency (60 ml/20 L water);

Treatment III (BT10): Bacillus Thuringiensis sprayed at 10 days frequency (20 g/20 L water);

Treatment IV (NABT): Neem Azal mixed with Bacillus Thuringiensis sprayed at 10 days frequency with the same rate as other treatment;

Treatment V (Ctrl): Kept as untreated control.

A water trap baited with sex pheromone was placed in the center of the greenhouse to monitor the male activity of T. absoluta.

\subsection{Data Recording}

Three complete leaves were collected randomly from each experimental plot at each sampling date, and brought to the lab to record the average number of mines and larva/leaf. Four plants were chosen randomly from each experimental plot and the \% of damaged fruits was assessed as follow: (Number of damaged fruits)/(Total number of fruits) $\times 100$.

To evaluate the effect of treatments as compared with control on yield parameters, total fruit/plant, fruit weight, diameter and height were recored from each experimental plot. In the second trial (2015), in addition to these parameters, soluble solids and acid fruit (Total acidity was expressed as percent of citric acid equivalent) content were measured by the means of refractometer and titration.Fruits were divided into four categories: $<70 \mathrm{~g}$ (I); 70-120 g (II); 121-200 g (III); > $200 \mathrm{~g}$ (IV) and the percent of each fruit category was recorded.

\subsection{Experimental Design and Statistical Analysis}

The two trials were conducted in randomized complete block design (RCBD) with four blocks. The experimental unit consisted of 20 plants. Repeated analysis of variance was performed for testing the effect of treatments, time and their interaction on the number of mines and larva/leaf and \% of damaged fruits by using SAS for windows V8. A post hoc Tukey's test $(\mathrm{p}<0.05)$ was used to discriminate among means of treatments. The normality assumption was not met for the number of captured adults of T. absoluta, number of mines/leaf and \% of damaged fruits of control plots in both greenhouses, therefore a Wilcoxon test was conducted instead of two sample $\mathrm{T}$ test. The sphericity assumption for repeated analysis was not also met, therefore the results of univariate were reported instead. 


\section{Results and Discussion}

\subsection{First Trial-2014}

The number of captured adults of tomato leafminer were significantly greater in the control greenhouse (Mdn $=$ 88 ) than in the double door greenhouse $\left(\mathrm{Mdn}=8\right.$ ), (Wilcoxon test, $\left.\mathrm{Z}=3.87, p=.0001, \mathrm{r}=.45^{\mathrm{ns}}\right)$. They ranged from (19 to 390) and (4.2 to 86) over 13 weeks (Figure 1). Since the same treatments were used in both greenhouses, these differences in control plots are likely due to the use of insect proof net. The number of mines/leaf in control plots of the control greenhouse $(\mathrm{CG}, \mathrm{Mdn}=6.3)$ differed significantly from the control plots of the double door greenhouse (DDG, $\mathrm{Mdn}=0.35), \mathrm{Z}=4.35, p<.0001, \mathrm{r}=0.36^{(\mathrm{p}=0.0175)}$. Regarding the \% of damaged fruits, a Wilcoxon test showed a significant difference between control plots of the (CG, Mdn =60) and (DDG, Mdn = 6), $\mathrm{Z}=5.3, p<.0001, \mathrm{r}=.51^{(\mathrm{p}=0.01)}$. These differences are also likely due to the use of insect proof net. These data agree with the previous findings obtained by (Cherif et al., 2013).

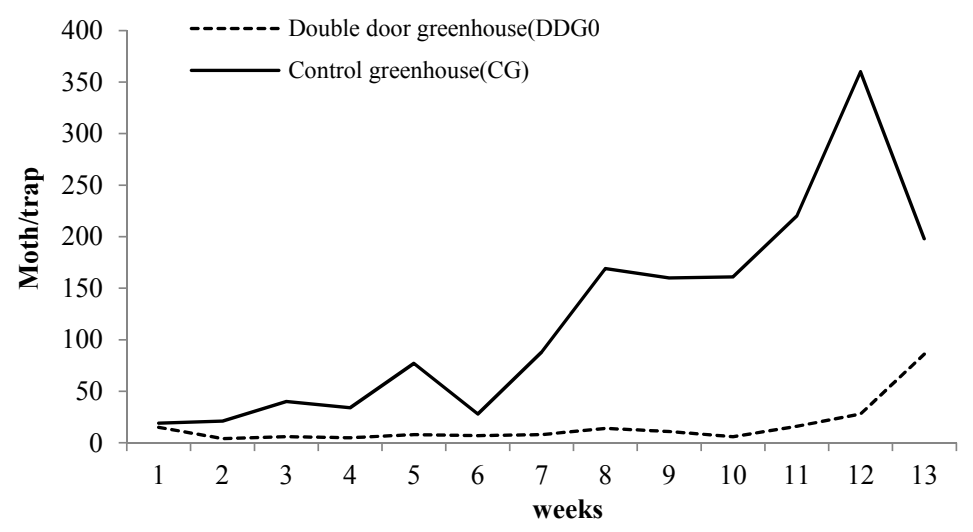

Figure 1. Dynamics of Tuta absoluta during spring season in both double door and control greenhouses in Lebaa Station (2014)

A repeated measures of anova was conducted to compare the effect of treatments, time and their interaction on the number of mines and larva/leaf and \% of damaged fruits in both control and double door greenhouses. Mauchly's test indicated that the assumption of sphericity was not met for all tested variables in both greenhouses and therefore, a Greenhouse-Geisser correction was used for time and time $\times$ treatment interaction. There was a significant effect of time on the number of mines and larva/leaf and $\%$ of damaged fruits in both greenhouses (Table 1). An interaction of time and treatment showed a significant effect on the three variables meaning that the effect of time differ by treatments (Table 1). Effect size of treatments was relatively higher than the effect size of time and time -treatment interaction.

Table 1. Results of repeated measures analysis (Anova) $\left(d f, F, P, \eta^{2}\right)$ for the first trial (2014)

\begin{tabular}{|c|c|c|c|c|c|c|c|c|c|c|c|c|}
\hline & \multicolumn{4}{|c|}{ Mine/Leaf } & \multicolumn{4}{|c|}{ Larva/Leaf } & \multicolumn{4}{|c|}{ \% Damaged Fruits } \\
\hline & $d f$ & $F$ & $P$ & $\eta^{2}$ & $d f$ & $F$ & $P$ & $\eta^{2}$ & $d f$ & $F$ & $P$ & $\eta^{2}$ \\
\hline \multicolumn{13}{|c|}{ Control greenhouse $(C G)$} \\
\hline Trt & 4,15 & 17.5 & $<.0001$ & .82 & 4,15 & 16.9 & $<.0001$ & .82 & 4,15 & 196.3 & $<.0001$ & .98 \\
\hline Time & 10,150 & 38.7 & $<.0001$ & .72 & 10,150 & 17.9 & $<.0001$ & .54 & 5,75 & 34.6 & $<.0001$ & .70 \\
\hline Trt $\times$ Time & 40,150 & 5.9 & $<.0001$ & .61 & 40,150 & 4.2 & $<.0001$ & .53 & 20,75 & 9.4 & $<.0001$ & .71 \\
\hline \multicolumn{13}{|c|}{ Double door greenhouse (DDG) } \\
\hline Trt & 4,15 & 17.2 & $<.0001$ & .82 & 4,15 & 19.9 & $<.0001$ & .84 & 4,15 & 27.7 & $<.0001$ & .88 \\
\hline Time & 10,150 & 24.4 & $<.0001$ & .62 & 10,150 & 9.8 & 0.0005 & .40 & 5,75 & 25.7 & $<.0001$ & .63 \\
\hline Trt $\times$ Time & 40,150 & 4.9 & 0.0005 & .57 & 40,150 & 4.97 & 0.0005 & .57 & 20,75 & 5.7 & $<.0001$ & .60 \\
\hline
\end{tabular}

Effect of treatments on the studied variables in both greenhouses was significant and therefore, a post hoc tukey test was conducted. The test showed a significant effect of treatments as compared with control on the number of 
mines and larva/leaf and the $\%$ of damaged fruits in both control and double door greenhouses. The results in the Table 2 show no significant differences between treatments themselves except for the \% of damaged fruits in the control greenhouse where the significant was observed between Bt and NA15 treatments.

Table 2. Means and standard deviation of mines/leaf $(\mathrm{M} / \mathrm{L})$, larva/leaf $(\mathrm{L} / \mathrm{L})$ and percent of damaged fruits $(\% \mathrm{DF})$ as affected by treatments in both DDG and CG greenhouses of the first trial (2014)

\begin{tabular}{|c|c|c|c|c|c|c|}
\hline \multirow{2}{*}{ Treatments } & \multicolumn{3}{|c|}{ Control greenhouse } & \multicolumn{3}{|c|}{ Double door greenhouse } \\
\hline & $\mathrm{M} / \mathrm{L}$ & $\mathrm{L} / \mathrm{L}$ & $\% \mathrm{DF}$ & $\mathrm{M} / \mathrm{L}$ & $\mathrm{L} / \mathrm{L}$ & $\% \mathrm{DF}$ \\
\hline NA10 & $3.9 \pm 0.7 b$ & $0.6 \pm 0.1 \mathrm{~b}$ & $9.3 \pm 0.5 b c$ & $0.5 \pm 0.4 \mathrm{~b}$ & $0.03 \pm 0.1 \mathrm{~b}$ & $2.0 \pm 0.6 \mathrm{~b}$ \\
\hline NA15 & $1.7 \pm 0.8 b$ & $0.2 \pm 0.1 \mathrm{~b}$ & $4.0 \pm 1.0 \mathrm{c}$ & $0.4 \pm 0.1 \mathrm{~b}$ & $0.06 \pm 0.1 \mathrm{~b}$ & $1.3 \pm 0.2 b$ \\
\hline NABT & $2.4 \pm 0.3 b$ & $0.3 \pm 0.1 \mathrm{~b}$ & $7.5 \pm 0.9 \mathrm{bc}$ & $0.5 \pm 0.2 b$ & $0.13 \pm 0.2 b$ & $1.7 \pm 0.3 b$ \\
\hline BT & $1.9 \pm 0.7 \mathrm{~b}$ & $0.3 \pm 0.1 \mathrm{~b}$ & $9.8 \pm 2.5 b$ & $0.6 \pm 0.2 b$ & $0.1 \pm 0.1 \mathrm{~b}$ & $1.9 \pm 0.4 b$ \\
\hline Control & $10.9 \pm 4.8 \mathrm{a}$ & $1.7 \pm 0.4 \mathrm{a}$ & $45.6 \pm 4.6 \mathrm{a}$ & $3.2 \pm 1.0 \mathrm{a}$ & $0.9 \pm 0.2 \mathrm{a}$ & $6.4 \pm 1.6 \mathrm{a}$ \\
\hline
\end{tabular}

Note. Columns with different letters are significantly different (Tukey's test, $p<0.05$ ).

\subsection{Second Trial-2015}

Figure 2 shows the dynamics of tomato leafminer adults through the spring growing season on tamoato crop in the CG greenhouse. The counted moths ranged from 37 to 428 moth/trap/week. The Maximum captures were observed at the first week of June.

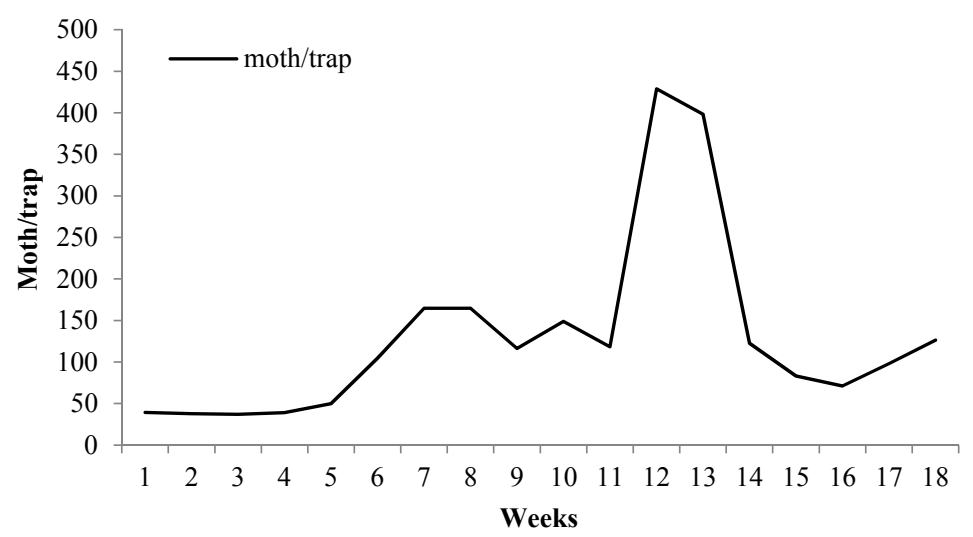

Figure 2. Dynamics of Tuta absoluta during the spring growing season of tomato crop planted in control geenhouse in Lebaa Station, 2015

As in the first trial of 2014, nearly the same patern of effect of treatments, time and their interaction on the studied variables was observed. Repeated analysis of variance showed a relatively low effect size of time on the number of larva/leaf and \% of damaged fruits (Table 3). Effect of treatments, time and their interaction on the number of mines and larva/leaf and \% of damaged fruits was significant. A post hoc tukey test showed a significant effect of treatments as compared with control on the three studied parameters. No significant differences were indicated between treatments themselves in regard to these parameters (Table 3). 
Table 3. Results of repeated measures analysis (Anova) $\left(d f, F, P, \eta^{2}\right)$ of the effect of time, treatment (Trt) and their interaction on the number of mine and larva/leaf and \% of damaged fruit in the second trial (2015)

\begin{tabular}{|c|c|c|c|c|c|c|c|c|c|c|c|c|}
\hline & \multicolumn{4}{|c|}{ Mine/leaf } & \multicolumn{4}{|c|}{ Larva/leaf } & \multicolumn{4}{|c|}{$\%$ damaged fruits } \\
\hline & $d f$ & $F$ & $P$ & $\eta^{2}$ & $d f$ & $F$ & $P$ & $\eta^{2}$ & $d f$ & $F$ & $P$ & $\eta^{2}$ \\
\hline Trt & 4,15 & 78.4 & $<.0001$ & .95 & 4,15 & 20.4 & $<.0001$ & .84 & 4,15 & 40 & $<.0001$ & .91 \\
\hline Time & 16,240 & 41.9 & $<.0001$ & .74 & 16,240 & 4.6 & 0.0042 & .24 & 8,120 & 3.7 & 0.037 & .20 \\
\hline Trt*Time & 64,240 & 10.6 & $<.0001$ & .74 & 64,240 & 1.8 & 0.578 & .33 & 32,120 & 2.7 & 0.0242 & .42 \\
\hline
\end{tabular}

Table 4. Average values of mines/leaf (M/L), larva/leaf $(\mathrm{L} / \mathrm{L})$ and percent of damaged fruits $(\% \mathrm{DF})$ as affected by treatments in CG greenhouse of the second trial (2015)

\begin{tabular}{llll}
\hline Treatments & $\mathrm{M} / \mathrm{L}$ & $\mathrm{L} / \mathrm{L}$ & $\% \mathrm{DF}$ \\
\hline NA10 & $4 \pm 1.4 \mathrm{~b}$ & $0.3 \pm 0.1 \mathrm{~b}$ & $1.3 \pm 1.5 \mathrm{~b}$ \\
NA15 & $3.5 \pm 0.8 \mathrm{~b}$ & $0.2 \pm 0.3 \mathrm{~b}$ & $1.2 \pm 0.5 \mathrm{~b}$ \\
NABT & $1.6 \pm 0.2 \mathrm{~b}$ & $0.2 \pm 0.1 \mathrm{~b}$ & $0.4 \pm 0.6 \mathrm{~b}$ \\
BT & $4.1 \pm 1.3 \mathrm{~b}$ & $0.3 \pm 0.1 \mathrm{~b}$ & $1.8 \pm 2.2 \mathrm{~b}$ \\
Control & $14.9 \pm 1.6 \mathrm{a}$ & $0.9 \pm 0.3 \mathrm{a}$ & $19.6 \pm 4.6 \mathrm{a}$ \\
\hline
\end{tabular}

Note. Columns with different letters are significantly different (Tukey's test, $p<0.05$ ).

\subsection{Agronomic Traits}

The results showed no significant differences between treatments and control regarding total number of fruits/plant in both DDG and CG greenhouses of the first trial respectively $\left(F(4,15)=0.98, p=0.448, \eta^{2}=.12\right.$; $\left.F(4,15)=0.41, p=0.8, \eta^{2}=.09\right)$.

In the second trial (2015), The results showed no significant differences between treatments and control regarding total number of fruits/plant , acidity and brix degree respectively $\left(F(4,15)=1.59, p=0.227, \eta^{2}=.30\right.$; $\left.\mathrm{F}(4,15)=0.82, \mathrm{p}=0.53, \eta^{2}=.18 ; \mathrm{F}(4,15)=0.66, \mathrm{p}=0.63, \eta^{2}=.15\right)$. Most of the fruits occurred between the second and third categories which accounted for about $70-80 \%$. This reflects variety attributes.

All treatments significantly reduced the number of mines, larva and damaged fruits as compared with control. There was not significant diffirence between NA10 and NA15. Applying NA at 15 days frequency kept the damaged caused by tomato leafminer at low levels. The advantage of applying NA at 15 days frequency was to reduce the number of sprays per season as compared with NA10. These results agree with the result obtained by Yankova (2014) reported that the highest effectiveness of neem Azal was recorded after 15 days. Our results of mixing Neem azal with Bt agree with the findings obtained by (Mohammed, 2002; Abbas, 2011) reported in their work the high efficacy of mixing BT with other biopesticides. Using BT alone also showed a significant difference as compared with control for the same studied parameters.

\section{Conclusions}

This study is the first assessment of the performance of two biopesticides in Lebanon on Tuta absoluta. Both two biopesticides were effective in reducing the damage made by the larva on fruit and leaves. The results obtained are consistent for two successive years. Mixing the two biopesticides has shown a significant effect in reducing the number of mines and the $\%$ of damaged fruits. Using neem azal in a 15-day frequency could be recommended instead of the 10 days frequency as no significant differences between them were observed. Number of mines/leaf and \% of damaged fruit were affected by the maintenance type of the greenhouse. Crop yield parameters were not affected by the adopted treatments.

\section{Acknowledgements}

The Managing Board of the Lebanese Agricultural Research Institute (LARI)-Lebanon is gratefully acknowledged for financial support. Special thanks are due to the administrative and technical staff of the Litani River Authority for their support and offering greenhouses. Ms. Elsa Chdid (master I student at Lebanese university), and technical staff of Lebaa station (M. Haris, K. Ghandour, and M. Abou Elrish) are thankful for their help. 


\section{References}

Abbas, S. (2010/2011) Tomato leaf miner Tuta absoluta (Meyrick, 1917) (Lepidoptera: Gelechiidae): The old and new challenge (Thesis, Universita Degli Studi Di Palermo).

Biondi, A., Zappalà, L., John, D. S., \& Desneux, N. (2013). Do Biopesticides Affect the Demographic Traits of a Parasitoid Wasp and Its Biocontrol Services through Sublethal Effects? PloS One, 8(9), e76548. https://doi.org/10.1371/journal.pone.0076548

Campos, M. R., Rodrigues, A. R., Silva, W. M., Silva, T. B., Silva, V. R., Guedes, R. N., \& Siqueira, H. A. (2014). Spinosad and the Tomato Borer Tuta absoluta: A Bioinsecticide, an Invasive Pest Threat, and High Insecticide Resistance. PloS One, 9(8), e103235. https://doi.org/10.1371/journal.pone.0103235

Cherif, A., Mansour, R., \& Grissa-Lebdi, K. (2013). Biological aspects of tomato leafminer Tuta absoluta (Lepidoptera: Gelechiidae) in conditions of Northeastern Tunisia: Possible implications for pest management. Environmental and Experimental Biology, 11, 179-184.

Cuthbertson, A., Mathers, J., Lisa, F. B., Korycinska, A., Luo, W., Jacobson, R., \& Northing, P. (2013). Population Development of Tuta absoluta (Meyrick) (Lepidoptera: Gelechiidae) under Simulated UK Glasshouse Conditions. Insects, 4, 185-197. https://doi.org/10.3390/insects4020185

Desneux, N., \& Luna, M. (2011). The invasive South American tomato pinworm, Tuta absoluta, continues to spread in Afro-Eurasia and beyond: The new threat to tomato world production. J Pest Sci, 84, 403-408. https://doi.org/10.1007/s10340-011-0398-6

EPPO (European and Mediterranean Plant Protection Organization). (2005). Data sheets on quarantine pests, “Tuta absoluta". EPPO Bulletin, 35, 434-435.

FAO. (2016). Introducing IPM to Lebanese farmers: Reducing the risk of "Tomato Borer" invasive plant pest. Management of Tomato Borer: Tuta absoluta in Near East Region. May, 2016.

Gebrelibanos, G. (2015). Tuta absoluta: A Global Looming Challenge in Tomato Production, Review Paper. Journal of Biology, Agriculture and Healthcare, 5(14).

Gonzalez-Cabrera, J., Molla, O., Monton, H., \& Urbaneja, A. (2011). Efficacy of Bacillus thuringiensis (Berliner) in controlling the tomato borer, Tuta absoluta (Meyrick) (Lepidoptera: Gelechiidae). BioControl, 56(1), 71-80. https://doi.org/10.1007/s10526-010-9310-1

Guedes, P., \& Picanco, M. C. (2012). The tomato borer Tuta absoluta in South America: Pest status, management and insecticide resistance. EPPO Bulletin, 42(2), 211-216. https://doi.org/10.1111/epp.2557

Guedes, S., \& Siqueira, H. (2011). The tomato borer Tuta absoluta: Insecticide resistance and control failure. CAB Reviews Perspectives in Agriculture Veterinary Science Nutrition and Natural Resources.

IRAC. (2011). Tuta absoluta-The Tomato Leafminer or Tomato Borer. Recommendations for Sustainable and Effective Resistance Management. The Insecticide Resistance Acton Committee. Retrieved from http://www.irac-online.org/content/uploads/Tuta_brochure_print-version_11Oct11.pdf

Judit, A., \& Gabarra, R. (2011). Side effects of selected insecticides on the Tuta absoluta (Lepidoptera: Gelechiidae) predators Macrolophus pygmaeus and Nesidiocoris tenuis (Hemiptera: Miridae). Journal of Pest Science, 84(4), 513-520. https://doi.org/10.1007/s10340-011-0384-z

Khater, H. M. (2012). Prospects of botanical biopesticides in insect pest management. Pharmacologia, 3(12), 641-656. https://doi.org/10.5567/pharmacologia.2012.641.656

Koul, O., \& Wahab, S. (2004). Neem: Today and in the New Millennium. Springer Science + Business Media, Inc. https://doi.org/10.1007/1-4020-2596-3

Lietti, M. M., Botto, E., \& Alzogaray, R. (2005). Insecticide Resistance in Argentine Populations of Tuta absoluta (Meyrick) (Lepidoptera: Gelechiidae). Neotropical Entomology, 34(1), 113-119. https://doi.org/ 10.1590/S1519-566X2005000100016

Lobos, E., Occhionero, M., Werenttzky, D., Fernanadez, J., Gonzalez, J., Rodriguez, C., ... Oehlschlager, A. C. (2013). Optimization of a Trap for Tuta absoluta Meyrick (Lepidoptera: Gelechiidae) and Trials to Determine the Effectiveness of Mass Trapping. Neotrop Entomol, 42, 448-457. https://doi.org/10.1007/ s13744-013-0141-5 
Marčić, D., Ogurlić, I., Prijović, M., \& Perić, P. (2009). Effectiveness of Azadirachtin (NeemAzal-T/S) in Controlling Pear Psylla (Cacopsylla pyri) and European Red Mite (Panonychus ulmi). Pestic. Phytomed. (Belgrade), 24, 123-131. https://doi.org/10.2298/PIF0902123M

Megido, R., Haubruge, E., \& Verheggen, F. (2013). Pheromone-based management strategies to control the tomato leafminer, Tuta absoluta (Lepidoptera: Gelechiidae). Biotechnol Agron. Soc. Environ., 17(3), 475-482.

Mohammed, L., \& Alawad, E. A. (2002). Effects of Bacillus thuringiensis var. aizawai and NeemAzalT/S against the immature stages of the African bollworm Helicoverpa armigera (Hübner) (Lepidoptera: Noctuidae) (B.Sc. Agric. (Hons.) SUST, October).

NAPPO. (2012). SP1, Surveillance Protocol for the Tomato Leaf Miner, Tuta absoluta, for NAPPO Member Countries. March 19, 2013.

Nazarpour, L., Yarahmadi, F., Saber, M., \& Rajabpour, A. (2016). Short and long term effects of some bio-insecticides on Tuta absoluta Meyrick (Lepidoptera: Gelechiidae) and its coexisting generalist predators in tomato fields. J. Crop Prot., 5(3), 331-342. https://doi.org/10.18869/modares.jcp.5.3.331

Savino, S., Coviella, C., \& Luna, M. (2012). Reproductive Biology and Functional Response of Dineulophus phtorimaeae, a Natural Enemy of the Tomato Moth, Tuta absoluta. J Insect Sci, 12, 153. https://doi.org/10.1673/031.012.15301

Shabozoi, N., Abro, G. H., Syed, T. S., \& Awan, M. S. (2011). Economic Appraisal of Pest Management Options in Okra. Pakistan J. Zool., 43(5), 869-878.

Siqueira, H., Guedes, R., \& Picanço, M. C. (2010). Cartap resistance and synergism in populations of Tutta absoluta (Lep., Gelechiidae). J. Appl. Ento., 124, 233-238. https://doi.org/10.1046/j.1439-0418.2000. 00470.x

Siqueira, H., Guedes, R., Fragoso, D. B., \& Magalha Äes, L. C. (2001). Abamectin resistance and synergism in Brazilian populations of Tuta absoluta (Meyrick) (Lepidoptera: Gelechiidae). International Journal of Pest Management, 47(4), 247-251. https://doi.org/10.1080/09670870110044634

Siqueira, H., Narciso, R., Guedes, R., \& Picanço, M. C. (2000). Insecticide resistance in populations of Tuta absoluta (Lepidoptera: Gelechiidae). Agricultural and Forest Entomology, 2(2), 147-153. https://doi.org/ 10.1046/j.1461-9563.2000.00062.x

Urbaneja, A., González-Cabrera, J., Arnó, J., \& Gabarra, R. (2012). Prospects for the biological control of Tuta absoluta in tomatoes of the Mediterranean basin. Pest Management Science, 68(9), 1215-1222. https://doi.org/10.1002/ps.3344

Yankova, V., Valchev, N., \& Markova, D. (2014). Effectiveness of phytopesticide Neem Azal T/S ${ }^{\circledR}$ against tomato leaf miner (Tuta absoluta Meyrick) in greenhouse tomato. Bulgarian Journal of Agricultural Science, 20(5), 1116-1118.

\section{Copyrights}

Copyright for this article is retained by the author(s), with first publication rights granted to the journal.

This is an open-access article distributed under the terms and conditions of the Creative Commons Attribution license (http://creativecommons.org/licenses/by/4.0/). 